Çuhadaroğlu, E.O. \&Yılmaz, K. / Sosyal Bilimler Araştırmaları Dergisi. 1, (2007): 77-97

\title{
Sınıf İçi Gözlem Araç ve Teknikleri: Kavramsal Bir Çözümleme
}

Ebru Oğuz Çuhadaroğlu ${ }^{a}$

\section{Kürşad Yılmaz ${ }^{b}$}

\section{Özet}

Günümüzde, denetim ve değerlendirme etkinliklerinin sadece form kullanılarak yapılamayacağı vurgusu artmıştır. Artık eğitim ortamlarında olup bitenlerin daha iyi gözlenmesi ve ardındaki gerçeklerin ortaya konulması gerektiği belirtilmektedir. Bu noktada gözlem, sınıf içi gözlem ve yeni değerlendirme tekniklerinin kullanılması gerekmektedir. $\mathrm{Bu}$ anlamda bu çalışmanın amacı denetim ve değerlendirme çalışmalarında kullanılabilecek olan sınıf içi gözlem teknikleri hakkında bilgi vermektir. $\mathrm{Bu}$ amaçla ilk önce gözlem ve sınıf içi gözlem kavramları açıklanmıştır. Daha sonra ise sınıf içi gözlem teknikleri hakkında bilgi verilmiştir. Çalışmada, 11 sınıf içi gözlem tekniği tanıtılmıştır. Bu teknikler şunlardır; Öğretmenin Sözel Davranışları, Öğretmen Soruları, Öğrencilerin Görev ve Görev Dışı Davranışları, Sözel Akış Şeması, Öğretmenin Hareket Şeması, Dönüt, Öğrenci-Öğretmen Etkileşimi, Tarafsız Açık Uçlu Anlatım Araçları, Katılanların Açık Uçlu Gözlemleri, Öğrenci Merkezli Öğrenme Gözlemleri, Sözel Olmayan Teknikler.

Anahtar sözcükler: Gözlem, sınıf içi gözlem, denetim

\section{Classroom Observation Tools and Techniques: A Conceptual Analysis}

\begin{abstract}
In present days, it is seen that the emphasis that activities of the inspection and the evaluation can not be made only by the ways of forms, increases. Anyhow the happening in education environment should be observed better; the background story should be put forth for considerations are stated. At this point, observation, observation in class and new evaluation techniques are required to be used. In this context, the aim of this work is to give information about observation techniques in class which can be used in inspection and evaluation activities. For this purpose, primarily observation and observation concept in class are explained. Subsequently, it is given information about observation techniques in class. In this work, 11 observation techniques in class are tried to be described. These techniques are; Teacher Verbal Behaviors, Teacher Questions, Student On-Task and Off-Task Behaviors, Diagram of Verbal Flow,
\end{abstract}

${ }^{a}$ Araş. Gör. ,Ankara Üniversitesi, Eğitim Bilimleri Fakültesi, Ankara.

${ }^{\mathrm{b}}$ Araş. Gör. Dr., Dumlupınar Üniversitesi, Eğitim Fakültesi, Kütahya. 
Çuhadaroğlu, E.O. \&Yılmaz, K. / Sosyal Bilimler Araştırmaları Dergisi. 1, (2007): 77-97

Diagram of Teacher Space Utilization, Feedback, Teacher-Pupil Interaction, Detached Open Ended Narrative Tool, Participant Open Ended Observation, Child-Centered Learning Observation and Nonverbal Techniques.

Keywords: Observation, classroom observation, supervision

\section{Giriş}

Denetim ve değerlendirme, yönetim etkinliklerinin vazgeçilmez süreçlerinden biridir. Bir yönetim süreci olarak denetim ve değerlendirme, örgütün amaçları doğrultusunda işleyip işlemediğinin belirlenmesi, eksikliklerin belirlenmesi ve giderilmesi, iyi yönlerin vurgulanması, yeni uygulamaların örgüte tanıtılması gibi pek çok sebeple önemli görülmektedir. Diğer örgütlerde olduğu gibi eğitim örgütlerinde denetim etkinlikleri çok önemlidir. Eğitim örgütlerinde denetim etkinliklerinin zorluğu, bu önemi daha da artırmaktadır. Özellikle Türk eğitim sistemi gibi, denetim sisteminde bir takım sorunların yaşandığı ülkelerde denetim etkinlikleri daha da önemli bir hale gelmektedir. $\mathrm{Bu}$ önemi artıran noktalardan birisi de Türkiye'deki eğitim denetmeni sayısının azlığı ve kullanılan denetim tekniklerinin amaca hizmet etme oranının düşük olmasıdır. Bu noktada eğitim denetmenlerinin sınıf denetimlerine fazla zaman ayıramadıkları ve yapılan denetimin de etkisiz kaldığı söylenebilir. Bu eksikliklerin giderilmesi ve sınıf denetiminin daha etkili bir hale getirilmesi için bir takım öneriler getirilebilir. Bu önerilerden birisi de sınıf içi gözlem teknikleri konusunda eğitim paydaşlarının bilgilendirilmesidir. $\mathrm{Bu}$ amaçla bu çalışmada sınıf içi gözlem teknikleri hakkında bilgi verilmeye çalışılmıştır. İlk önce gözlemin ne olduğu üzerinde durulmuş, daha sonra, sınıf içi gözlemin amaçları, özellikleri, ilkeleri ve türleri hakkında bilgi verilmiştir.

Denetim yaklaşımlarının her birinde (bilimsel, sanatsal, öğretimsel ve klinik denetim) gözlem yöntemi kullanılmaktadır. Denetim yaklaşımlarının amacına göre, gözlem yöntemlerinin amacı ve kullanılış şekilleri değişmektedir. Bilimsel denetimde gözlem daha çok, puan vermek, davranışların standartlığa uygunluğu ölçmek amacıyla kullanılırken, sanatsal denetim modelinde sınıfta meydana gelen önemli ayrıntıların gözlenmesinde ve öğretmene açıklanmasında kullanılmaktadır. Öyle ki tamamen gözlem üzerine kurulan denetim yaklaşımları da vardır. Sergiovanni ve Starratt'a göre (1993) klinik denetim 
Çuhadaroğlu, E.O. \&Yılmaz, K. / Sosyal Bilimler Araştırmaları Dergisi. 1, (2007): 77-97

gözlem esasına dayanmaktadır. Çünkü klinik denetim, öğretmenlerin ya da sınıfın değerlendirilmesi sırasında yakın gözlem, ayrıntılı gözlem verileri, öğretmen ve denetmen arasında yüz yüze etkileşim, iki kişinin mesleki ilişkilerinde yakınlığını sağlayan bir denetim yaklaşımıdır (Acheson ve Gall, 1997). Aşağıda gözlemin ne olduğu ve hangi amaçlarla yapıldığı hakkında bilgi verilmiştir.

\section{Gözlem}

Hangi yöntem kullanılırsa kullanılsın, öğretmenlerin değerlendirilmesi, zor ve karmaşı bir iştir. Öğretmenlerin değerlendirilmesi için olası birçok yöntem vardır, fakat bunları uygulamak güç ve sınırlıdır. Değerlendirmede ipuçlarını elde etmenin yaygın yollarından biri, öğretmenlerin doğrudan gözlenmesidir (Stodolsky, 1990: 175). Gözlem belirli bir amaç için, bir nesne, olay ya da ilişkinin sistematik olarak incelenmesi süreci olarak tanımlanmaktadır. Bu süreç doğal koşullarda, olayın kendiliğinden belirdiği sırada ya da bilinçli ve planlı olarak hazırlanan deney koşullarında olabilmektedir (Özgüven, 2002). Bu anlamda gözlem, bakmaktan farklı, planlı ve sistemli bir eylemdir (Başar, 2000).

Gözlem, günlük yaşama katılma, ayak uydurma sürecidir. Sınıf ortamında da günlük yaşamda olduğu gibi hem öğretmen hem de öğrenci tarafından yapılan gözlemler yer almaktadır. Sınıf içinde ya da dışında yapılan gözlemlerin amacı var olan şartlara ayak uydurmaktır. Günlük yaşamda yaptığımız gözlemler informal gözlem; performansın değerlendirilebileceği, çok yönlü, amaçlı, dinamik eylem süreçleri ise formal düzeyde gözlemler olarak adlandırılmaktadır. Çok yönlü bu süreç içinde kimin kimi, nerede, hangi kurallar çerçevesinde, hangi gözlem aracıyla gözleyeceği ve hedeflenen amacın ne olması gerektiği gibi pek çok unsur vardır (Üstünlüoğlu, 2000).

Gözlem doğrudan gözlem ve dolaylı gözlem olarak ikiye ayrılır. Performans değerlendirmede ve denetimde her ikisi de kullanılmaktadır (Murphy ve Cleveland, 1995). Ancak temelde, yapılandırılmış gözlem ve yapılandırılmamış olmak üzere iki tip gözlem vardır. Yapılandırılmış gözlem gözlemcinin, genellikle belirli bir davranış ya da olay ile ilgili frekans, süre, büyüklük ve önemi belirlemeye dönük ölçüm yapmasıdır. Yapılandırılmamış 
Çuhadaroğlu, E.O. \&Yılmaz, K. / Sosyal Bilimler Araştırmaları Dergisi. 1, (2007): 77-97

gözlem ise gözlemcinin, temel olarak gözlenen kişinin davranışlarını izlemesi ve bu davranışların özellikleri ile ilgili notlar tutmasıdır (Hopkins ve Moore, 1993: 47).

Gözlem, denetim ile ilgili olarak, belirli bir zaman zarfında, belirli bir yerdeki olaylardan, etkileşimlerden, fiziki unsurlardan ve diğer olgulardan denetmenin haberdar olma etkinliği olarak (Goldhammer, Anderson ve Krajewski, 1980: 71) tanımlanmaktadır.

\section{Sınıf İçi Gözlem}

Sınıf içi süreçler ile ilgili çalışmalara 1960'lardan itibaren artan bir şekilde önem verilmektedir ve bununla ilgili yayınlanmış birçok çalışma bulunmaktadır. Bu bağlamda ABD'de bulunan birçok okulda, okul müdürleri, müdür yardımcıları ve diğer yöneticiler sınıf içi gözlemlere ve bu gözlemler ile ilgili tartışmalara çok zaman ayırmaktadırlar (Wragg, 1987: 23). Sınıf içi gözlemlere ve bununla ilgili tartışmalara önemli zaman ayrılmasında uygulanan mentorlük programlarının da etkisi vardır. Çünkü mentorlük programları, deneyimli öğretmenlerin deneyimsiz öğretmenlere rehberlik etmesi esasına dayanmakta ve bu çalışmalar daha çok deneyimli öğretmenlerin deneyimsiz öğretmenleri gözlemesi şeklinde olmaktadır.

Öğretmen gözlemlerinde kullanılan gözlem araçları öğrenci-öğretmen etkileşimi ve öğretmen davranışlarını kaydetmek amaçı ortaya çıkmıştır (Achilles ve Gutmore, 2006). Bu amaçla sınıf içi gözlem, genellikle öğretmenin sınıf içinde göstermiş olduğu performansın değerlendirilmesi amacıyla yapılmaktadır. Sınıf içi gözlemin amacı kişilerarası çeşitliliği anlamak ve öğrenciler arasında etkileşimi ortaya koymaktır (Pennekamp ve Allen, 1998). Bu anlamda sınıf içi gözlemlerde öğretim, sınıf yönetimi, ders planları, öğretim becerileri, öğretmen-öğrenci ilişkileri, öğrenci-öğrenci ilişkileri gibi özelliklere dikkat edilmesi gerekmektedir. Bu bağlamda gözlemin kullanılış amacı; kişi hakkında daha objektif davranabilmek ve onu daha iyi tanıyabilmek, gelişimini daha yakından takip edebilmek amacıyla çeşitli zamanlarda bireylerin anlamlı davranışlarını, becerilerini, tutumlarını, alışkanlıklarını, öğretmen-yönetici ve arkadaşlarıyla ilişkilerini anlamaya çalışmaktır. Poster ve Poster'a göre (1993: 
81) deneyimli gözlemciler, öğretim çıktılarını gözlemek yerine, öğretim sürecini ve bu sürecin dersin etkililiğini nasıl artırabileceğini gözlemektedirler.

Gözlem çalışmaları, değerlendirme ile ilgili veri kaynakları içinde en önemlisidir ve öğretmenlerin hangi öğretim becerilerine sahip olduklarının belirlenmesi açısından önemlidir (Peterson, 1995: 79). Angelo ve Cross'un da (1993) belirttiği gibi öğrencilerin öğrenmelerinin niteliği doğrudan öğretimin niteliği ile ilgilidir. Bu niteliğin belirlenmesi ve geliştirilmesinde gözlem ve gözlem teknikleri kullanılmaktadır. Gözlemin daha iyi sonuçlar verebilmesi için denetmen ve öğretmenin gözlem öncesi görüşmesi ve bir takım sorulara cevap bulmaları gerekmektedir. Bu sorular şunlardır (http://iteso.mx):

1. Sınıf içi gözlem yaşantısından ne öğrenilmek isteniyor?

2. Öğrencilerden ve diğer personelden ne gibi dönütler alınabilir?

3. Başka hangi davranışların gözlenmesi planlanıyor?

4. Denetmen gözlemden ne beklemektedir?

5. Denetmenin amacı nedir?

6. Planlanan etkinliklere öğrencilerin cevabı nasıl olur?

7. Sınıfa gözlem için gelen biri dersi nasıl etkiler?

8. Öğrenciler neye dikkat eder?

9. Öğrenciler nasıl sorular sorar?

Yukarıda da görüldüğü gibi cevaplanması gereken bu sorular bir anlamda gözlemin ve denetimin amacını ortaya koymaktadır. Bu soruların cevaplanması gözlemin amacına ulaşması açısından önemlidir. Çünkü beklentilere göre hareket edilmesi ve ne istendiğinin bilinmesi amaca ulaşmayı kolaylaştırabilir. Buradaki önemli bir nokta da, gözlemden sonra denetmen ve öğretmenin gözlem sonuçlarını birlikte değerlendirmeleri gereğidir. Gözlemden sonra üzerinde konuşulmayan ve sonuçları ile ilgili değerlendirme yapılmayan gözlemler amacına ulaşmamaktadır.

\section{Sınıf İçi Gözlem Araç ve Teknikleri}

Öğretmen değerlendirmede sık sık tartışılan konulardan birisi bu sürecin sadece teknik bir süreç olarak algılanmasıdır. Ancak öğretmen değerlendirme sadece teknik bir süreç değil, aynı zamanda sosyal, insani ve politik bir süreçtir

(Peterson, 1995: 51). Bu bağlamda gözlem araçlarının doğrudan değerlendirme 
Çuhadaroğlu, E.O. \&Yılmaz, K. / Sosyal Bilimler Araştırmaları Dergisi. 1, (2007): 77-97

amaciyla kullanılması bir takım sorunlar yaratabilmektedir. $\mathrm{Bu}$ sorunun giderilmesi için gözlem araç ve tekniklerinin yardımcı araçlar olarak kullanılmasında yarar vardır. Bu sorunun giderilmesinin yollarından birisi de denetmenin öğretmenle ilişkisinde yönetici olmamasıdır. Anlayış ve karşılıklı iletişime dayalı olarak denetmen, gözlem yöntemlerini kişiler arası etkileşimi cesaretlendirmek için kullanmalıdır. Kullanımı kolay gözlem teknikleri, öğretmenin sınıf davranışları hakkında bilgi sahibi olmasını kolaylaştırmaktadır. $\mathrm{Bu}$ gözlem araçları ve tekniklerinin kullanımı denetmen ile öğretmenin yakın olarak çalışmaları sayesinde, öğretmenin anlatımını daha iyi düzeye çıkarmakta ve öğrencilerin başarılarını artırmaktadır. Ancak bu teknikleri kullanmadan önce bir takım ilkeleri yerine getirmek gerekmektedir (Sullivan ve Glanz, 2005):

1. İyi denetim/değerlendirme amacından çok öğretmenin düşünme ve kavramaya dayalı tartışmasını gözlemeyi kapsamalıdır.

2. Denetmen, gözlem araçlarını kullanmanın öğretmeni geliştireceğine ve sınıfı hakkında bilgi sağlayacağına güvenmelidir.

3. Gözlemin iki basamağı vardır; birincisi, olayların tarif edilmesi, ikincisi olayların ne anlama geldiğinin anlaşılmasıdır.

4. Gözlem araç ve teknikleri öğretmen ve denetmen arasında karşılıklı işbirliği içinde seçilmelidir.

5. Gözlem yetenek ve uygulama gerektirmektedir.

6. Gözlemin sınırlarının farkında olmak gerekmektedir. Gözlem sırasında, sınıf içindeki bütün etkileşimi görmek çok zordur. Küçük grupların gözlenmesi ve öğretmenlerin sadece bir davranışının ölçülmesi daha kolay olabilmektedir.

7. Sınıfa girmeden önce gözlemci öğretmene sınıfta nerede oturacağını, öğrencilere kendini nasıl tanıtacağını söylemelidir.

8. Tek gözlem sonucuna göre karar verilmemelidir. Öğretmenlerin kötü günü olacağı gibi öğrencilerin de kötü günü olabilir. Bu sorunun giderilmesi için birden fazla gözlem yapılması gerekmektedir.

$\mathrm{Bu}$ ilkelere göre hareket edilmesi, kullanılan sınıf içi gözlem tekniklerinden elde edilen verimi artıracak ve sınıf içi gözlem tekniklerinin kullanımı sırasında ortaya çıkabilecek bir takım sorunları da ortadan 
kaldıracaktır. Yukarıda sıralanan ilkelerin yanı sıra gözlemin tarafsız ve objektif olmasına, gözlemcinin psikoloji ve pedagoji konularında yeterli bilgiye sahip olmasına, duyu organlarının kusursuz olmasına, gözlemin mümkün olduğu kadar değişik durum ve yerlerde yapılmasına da dikkat edilmelidir. Ayrıca gözlemci gözlenen davranışı nasıl olması gerektiği açısından değil olduğu gibi gözlemeli, gözlenen kişinin söylediklerinden daha çok yaptıklarını kaydetmelidir (Aydın, 2004).

Yukarıda da görüldüğü gibi gözlem yapacak kişinin hem gözlem yapılacak konu ile ilgili bilgisinin olması hem de tarafsız bir gözle görev yapması büyük önem taşımaktadır. Ayrıca gözlemin amacına ulaşabilmesi için gözlemin yeri, zamanı, süresi, sıklığı, amacı gibi konulara da dikkat edilmesi gerekmektedir. Gözlemin sık sık kullanıldığı alanlardan birisi de denetim etkinlikleridir. Denetim etkinliklerinde gözlem, sınıf içi etkinliklerin gözlenmesinde kullanılmakta ve bu tekniklere sınıf içi gözlem teknikleri adı verilmektedir.

Sınıf içi gözlem teknikleri ile ilgili olarak yapılan sınıflandırmalara ve belirtilen tekniklere birçok örnek verilebilir. Bu teknikler arasında anekdot kayıtları, kontrol listeleri, oran ölçekleri, portfolyolar (Airasian, 1994; Good ve Mulryan, 1990), harfi harfine kayıt, kontrol listeleri, öğrencilerin oturma yerlerine göre kayıt, sınıf etkileşimleri (Hopkins ve Moore, 1993), kontrol listeleri, örnek zaman incelemesi, kelimesi kelimesine kayıt, öğretmen sorularının analizi, yaratıcı düşünme sistemi, mantıksal-zihinsel süreçler yaklaşımı, öğretmen sorularının kaydedilmesi, sözel akış tekniği, öğretmen hareket şemaları (Hyman, 1986, Akt. Aydın, 2005; Acheson ve Gall, 1997) sayılabilir. Aşağıda sınıf içi gözlem tekniklerinden bazıları hakkında bilgi verilmiştir. Burada verilen sınıf içi gözlem teknikleri Nicel Yaklaşımlar ve Nitel Yaklaşımlar başlıkları altında incelenmiştir. Bu tekniklerin incelenmesinin sebebi kullanımı yaygın ve kolay olan teknikler olmalarıdır.

\section{Nicel Yaklaşımlar (Quantitative Approaches)}

Sınıf içi gözlem tekniklerine nicel yaklaşımlar başlığı altında, "sık kullanılan araçlara", "görsel araçlara" ve "durumsal araçlara" yer verilmiştir.

1. 
Çuhadaroğlu, E.O. \&Yılmaz, K. / Sosyal Bilimler Araştırmaları Dergisi. 1, (2007): 77-97

\section{Sık Kullanılan Araçlar (Categorical Frequency Tools)}

Sık kullanılan araçlar kategorisinde "öğretmenin sözel davranışları", "öğretmen soruları" ve "öğrencilerin görev ve görev dışı davranışları" araçlarına yer vermiştir.

a. Öğretmenin Sözel Davranışları (Teacher Verbal Behaviors). Bu aracın kullanımında, öğretmen ve gözlemcinin işbirliği ile öğretmen davranışlarını içeren ve yediden daha fazla olmayan bir davranış listesi hazırlanmaktadır. Bu davranışlara örnek olarak bilgi verme, soru sorma, cevap verme, övme, yön gösterme, cevapları doğrulama ve azarlama verilebilir. Hazırlanan listede bulunan davranışlar Tablo 1'deki gibi bir şablona kaydedilmekte ve frekansları çıkarılmaktadır. Frekanslar çıkarılırken belli bir zaman dilimi seçilmekte ve sadece belirlenen zaman dilimindeki öğretmen davranışları belirlenmektedir. Ayrıca sadece bir liste ile yetinilmemesi ve birden fazla gözlem yapılması gerekmektedir (Sullivan ve Glanz, 2005).

Tablo 1. Öğretmenin Sözel Davranışları

\begin{tabular}{|c|c|c|c|c|c|c|c|}
\hline \multicolumn{8}{|c|}{ Dersin başlama saati: } \\
\hline Dakika & $\begin{array}{l}\text { Bilgi } \\
\text { Verme }\end{array}$ & $\begin{array}{l}\text { Soru } \\
\text { Sorma }\end{array}$ & $\begin{array}{l}\text { Cevap } \\
\text { Verme }\end{array}$ & Övme & $\begin{array}{l}\text { Yön } \\
\text { Gösterme }\end{array}$ & $\begin{array}{l}\text { Cevapları } \\
\text { Doğrulama }\end{array}$ & Azarlama \\
\hline 1 & $\mathrm{X}$ & $\mathrm{x}$ & $\mathrm{x}$ & & & $\mathrm{x}$ & \\
\hline 2 & $\mathrm{x}$ & $\mathrm{x}$ & & & & & \\
\hline 3 & & & & $\mathrm{x}$ & & & $\mathrm{x}$ \\
\hline 4 & & $\mathrm{x}$ & & & $\mathrm{x}$ & & $\mathrm{x}$ \\
\hline 5 & $\mathrm{x}$ & & & & $\mathrm{x}$ & & \\
\hline 6 & & & $\mathrm{x}$ & & $\mathrm{x}$ & & $\mathrm{x}$ \\
\hline 7 & $\mathrm{X}$ & & $\mathrm{x}$ & & $\mathrm{x}$ & & \\
\hline 8 & $\mathrm{x}$ & & & $\mathrm{x}$ & $\mathrm{x}$ & & \\
\hline \multicolumn{4}{|c|}{ Dersin Bitiş Saati: } & Sınıf: & & & Tarih: \\
\hline
\end{tabular}

Kaynak: Glickman, C. D., Gordon, S. P. ve Ross-Gordon, J. (2004). Supervision and Instructional Leadership: A Developmental Approach. USA: Allyn ve Bacon. Akt: Sullivan ve Glanz, 2005. 
Çuhadaroğlu, E.O. \&Yılmaz, K. / Sosyal Bilimler Araştırmaları Dergisi. 1, (2007): 77-97

Tablo 1'de görüldüğü gibi öğretmen birinci dakikada, bilgi verme, soru sorma, cevap verme, cevapları doğrulama davranışlarını göstermiştir. Buna göre bu aracın, öğretmenin öğretim davranışları sırasında kullanabileceği sözlü davranışları belirlemeye dönük bir teknik olduğu söylenebilir. Bu anlamda bu aracın dersin işlenmesi sırasında kullanılması daha uygun olabilir. Bu araçta gözlemcinin sadece yukarıdaki şablonu doldurması yetmemektedir. Gözlemci, gözlemin süresini, alınan olumlu puanları, ders sürecinde olup bitenleri, gözlemin sonuçlarını ve bunun öğretmene aktarılması konularını da gözlem sürecinde dikkate alması gerekmektedir.

b. Öğretmen Soruları (Teacher Questions). Bu aracın kullanılabilmesi için kullanacak kişinin Bloom'un taksonomisi hakkında bilgi sahibi olması, öğretmen ve gözlemcinin belli bir zaman içinde sadece soruların niteliğine odaklanmakları gerekmektedir. Bu araçta, öğretmen ve gözlemci soruların analizinde Bloom'un taksonomisindeki bilgi, kavrama, uygulama, analiz, sentez ve değerlendirme kategorileri kullanmaktadır. Tekniğin kullanımı sırasında gözlemci sınıf içi gözlemde, öğretmenin sorduğu soruları dinlemekte ve Bloom'un taksonomisinin hangi basamağına denk düştüğüne karar vererek bir çetele tutmaktadır. Bu araçta sorulan sorular kayıt edilmemekte ama sorunun sorulma sıklığı kayıt edilmektedir. Öğretmenin sorularının dinlenilmesi için kayıt cihazı kullanılabilmektedir. Gözlem sonunda gözlemci, Tablo 2'de olduğu gibi toplam frekansı ve toplam içindeki yüzdeleri hesaplamakta ve gerekli yorumları ekleyebilmektedir (Sullivan ve Glanz, 2005). Tablo 2'de öğretmen sorularının analizinde kullanılacak olan Bloom'un taksonomisi ve bu teknik ile ilgili bir uygulamaya yer verilmiştir.

Tablo 2. Öğretmen Soruları

\begin{tabular}{|l|l|l|l|r|r|r|}
\hline $\begin{array}{l}\text { Soru } \\
\text { Kategorisi }\end{array}$ & $\begin{array}{l}\text { Frekans } \\
5 \\
\text { Dakika }\end{array}$ & $\begin{array}{l}\text { Frekans } \\
10 \\
\text { Dakika }\end{array}$ & $\begin{array}{l}\text { Frekans } \\
15 \\
\text { Dakika }\end{array}$ & Toplam & $\%$ & Yorumlar \\
\hline Değerlendirme & & $\mathrm{x}$ & $\mathrm{x}$ & 2 & 07 & - \\
\hline Sentez & & & & & 0 & $\begin{array}{l}\text { Sentez soruları } \\
\text { nerede sorulacak? }\end{array}$ \\
\hline Analiz & $\mathrm{xx}$ & & & 2 & 07 & $\begin{array}{l}\text { Analiz sorularının } \\
\text { yeri tartışılmalı. }\end{array}$ \\
\hline
\end{tabular}


Çuhadaroğlu, E.O. \&Yılmaz, K. / Sosyal Bilimler Araştırmaları Dergisi. 1, (2007): 77-97

Tablo 2'nin devamı

\begin{tabular}{|c|c|c|c|c|c|c|}
\hline Uygulama & & & $\mathrm{x}$ & 1 & 04 & $\begin{array}{l}\text { Uygulama soruları } \\
\text { tartışılabilir. }\end{array}$ \\
\hline Kavrama & $\mathrm{XXXX}$ & $\mathrm{xx}$ & $\mathrm{x}$ & 8 & 30 & $\begin{array}{lr}\mathrm{Bu} & \text { soruların } \\
\text { bazıları } & \text { nasıl } \\
\text { uygulama } & \text { sorusu } \\
\text { yapılabilir? } & \end{array}$ \\
\hline Bilgi & $\mathrm{XXXXXX}$ & $\mathrm{xxxx}$ & $\mathrm{xxxx}$ & 14 & 52 & $\begin{array}{l}\text { Bu sorular nasil üst } \\
\text { düzey soru haline } \\
\text { getirilebilir? }\end{array}$ \\
\hline \multicolumn{4}{|l|}{ Sinif: } & \multicolumn{3}{|c|}{ Dersin Bitiş Saati: } \\
\hline \multicolumn{7}{|c|}{$\begin{array}{l}\text { Kaynak: Glickman, C. D ve diğerleri. (2004). Supervision and Instructional } \\
\text { Leadership: A Developmental Approach. USA: Allyn ve Bacon. Akt: Sullivan ve } \\
\text { Glanz, } 2005 \text {. }\end{array}$} \\
\hline
\end{tabular}

Tablo 2'de de görüldüğü gibi öğretmen soruları aracında, soruların kendisi değil, Bloom'un taksonomisine göre hangi kategoriye girdiği önemlidir. Bu tekniğin kullanımı sırasında önemli olan, ders süresi içinde sorulan soru sayısı ve bu soruların nasıl tanımlandığıdır.

c. Öğrencilerin Görev ve Görev Dışı Davranışları (Student On-Task and Off-Task Behaviors). Bu araç, öğretmen soruları aracına göre daha çok uygulamayı gerektirmektedir. Gözlemci ve öğretmen öğrencilerin hangi davranışlarına odaklanacaklarına birlikte karar vermekte, öğrenci isimlerinin olduğu bir liste hazırlanmaktadır. Hazırlanan bu liste öğrencilerin oturma yerlerine göre de olabilmektedir. Gözlemci bu aracın uygulanması sırasında, sınıfın önünde bir yerde oturmalıdır. Çünkü öğrenciler gözlemci tarafından rahatça görülmelidir. Gözlemin süresi öğrenci sayısıyla orantılıdır. Bu araçta, gözlemler gözlenen öğrenci sayısına bağlı olarak, 5 dakikalık aralıklarda yapılmalıdır. Büyük sınıflarda davranışların türü azaltılarak gözlem yapılabilmektedir (Sullivan ve Glanz, 2005: 88). Bu araç ile ilgili örnek bir çalışmaya Tablo 3'de yer verilmiştir. 
Çuhadaroğlu, E.O. \&Yılmaz, K. / Sosyal Bilimler Araştırmaları Dergisi. 1, (2007): 77-97

Tablo 3. Öğrencilerin Görev ve Görev Dışı Davranışları

\begin{tabular}{|l|l|l|l|l|l|l|l|}
\hline Öğrenci & $\mathbf{9 . 0 0}$ & $\mathbf{9 . 0 5}$ & $\mathbf{9 . 1 0}$ & $\mathbf{9 . 1 5}$ & $\mathbf{9 . 2 0}$ & $\mathbf{9 . 2 5}$ & $\mathbf{9 . 3 0}$ \\
\hline Ahmet & D. İ. & K & Ö.D & D.İ. & O & Ö.D & O \\
\hline Ayşe & Ö.D & O & D.İ. & Ö.D & K & D.İsiz & K \\
\hline Ali & O & SD & K & O & SD & S & SD \\
\hline Mehmet & K & D.İsiz & S & K & S & SD & S \\
\hline Berna & S & S & D.İsiz & S & D.İsiz & K & D.İsiz \\
\hline Cem & D.İsiz & GD & S & D.İsiz & Ö.D & O & Ö.D \\
\hline
\end{tabular}

D.İ: Dersle ilgili.

Ö.D: Öğretmenle ders işliyor

K: Konuşuyor

O: Oynuyor S: Sırasında oturmuyor S.D: Sınıf dışında $\quad$ D.İsiz: Dersle ilgisiz

Kaynak: Glickman, C. D ve diğerleri. (2004). Supervision and Instructional Leadership: A Developmental Approach. USA: Allyn ve Bacon. Akt: Sullivan ve Glanz, 2005.

Yukarıda da görüldüğü gibi bu çalışmada 6 öğrenci 5'er dakikalık (300 saniye) sürelerde gözlenmiştir. Buna göre her bir öğrenci 50 saniye kadar gözlenmiş̧ir. Örneğin Ahmet isimli öğrenci ilk gözlem sırasında "dersle ilgilenmiş", ikinci gözlem sırasında "konuşmuş", üçüncü gözlemde "öğretmenle ders işlemiş", dördüncü gözlem sırasında "dersle ilgilenmiş", beşinci gözlem sırasında "oynamış", altıncı gözlem sırasında "öğretmenle ders işlemiş ve yedinci gözlem sırasında ise "oynamıştır”. Bu teknik görüldüğü gibi öğretmenin ders işlemesi sırasında öğrencilerin sergilemiş oldukları davranışların belirlenmesi açısından önemlidir.

\section{Görsel Araçlar (Visual Diagramming Tools)}

Görsel araçlar başlığı altında ise "sözel akış şeması" ve "öğretmen hareket şemasına" yer verilmiştir. Görsel araçlar, sınıf içinde gözle görünür şekilde neler olduğunun belirlenmesinde (resmedilmesinde) kullanılmaktadır. Burada sadece iki örnek incelenmiştir. Ancak bunların sayısını artırmak mümkündür. $\mathrm{Bu}$ tekniklerin kullanımı sırasında video gibi elektronik kayıt cihazları da kullanılabilmektedir. 
Çuhadaroğlu, E.O. \&Yılmaz, K. / Sosyal Bilimler Araştırmaları Dergisi. 1, (2007): 77-97

a. Sözel Akış Şeması (Diagram of Verbal Flow). Bu araçta hangi derste hangi zaman diliminin gözleneceği ile ilgili olarak fikir birliği sağlanması gerekmektedir. Genellikle 30 dakikalık zaman dilimlerinde gözlemler yapılmaktadır. Bu araçta gözlemci, öğretmenin öğrencilere ne kadar söz hakk1 verdiğini ve öğrenciler arasındaki etkileşimi belirlemeye çalışmaktadır. Gözlem süresi boyunca öğretmenin hangi öğrencilere kaçar defa söz verdiği yazılmakta, hangi öğrencinin en çok söz aldığı ve derse katıldığı böylece ortaya çıkmaktadır. Bundan dolayı bu araç kullanılmadan önce gözlem yapılacak sınıfın oturma düzeni ile ilgili bir oturum planı çıkarılmalıdır. Bu form genellikle standart olmamaktadır. Çünkü her sınıfın oturum düzeni farklılıklar göstermektedir. Sözel akış şeması aracı Şekil 1'de gösterilmeye çalışılmıştır (Sullivan ve

Glanz, 2005).

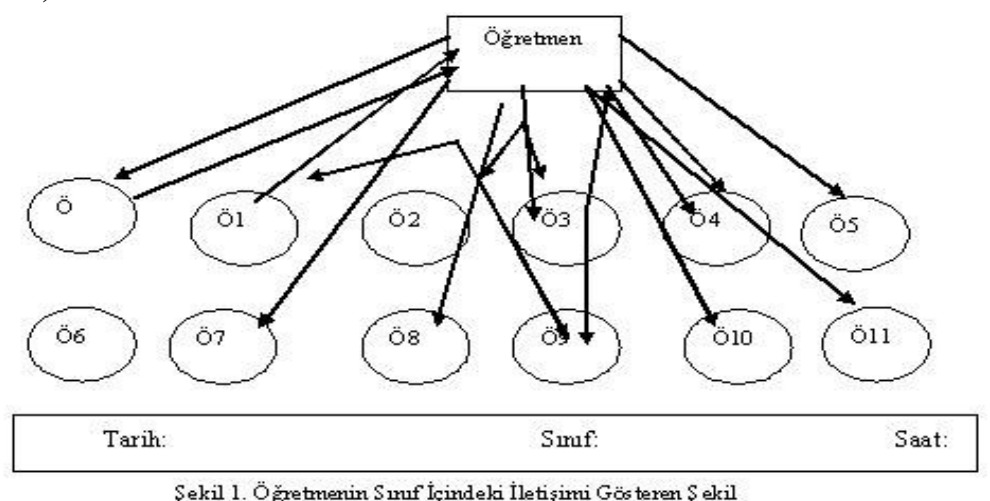

Yukarıda da görüldüğü gibi bu araç daha çok kimin kim ile iletişim kurduğunun ortaya konulmasına yarayan bir tekniktir. Gözlemci bu aracın kullanımı sırasında öğretmen ile öğrenciler arasındaki sözel akışı oklar yardımı ile göstermektedir. Şekil 1'de de görüldüğü gibi öğretmenin daha çok ön sıralarda oturan öğrenciler ile iletişim kurduğu görülmektedir. Aydın'a göre (2005) sözel akış aracı, öğretmenlere kendi sözel davranışlarındaki yanlılıklar ve öğrenciler arasındaki sözel katılım farklılıklarını ortaya koyma konusunda büyük yardımlar sağlamaktadır. 
Çuhadaroğlu, E.O. \&Yılmaz, K. / Sosyal Bilimler Araştırmaları Dergisi. 1, (2007): 77-97

b. Öğretmenin Hareket Şeması (Diagram of Teacher Space Utilization). $\mathrm{Bu}$ aracın kullanımına geçilmeden önce sınıfın bir krokisi çizilmelidir. Gözlem yine üzerinde anlaşılan, belli bir zaman diliminde yapılmaktadır. Öğretmenin sınıf içindeki hareketleri gözlenmekte ve bu krokiye işlenmektedir. Gözlemci hareketleri kaydederken aynı zamanda hareketin zamanını da krokiye işlemektedir. Bu aracın kullanımı ile ilgili örnek bir çalışmaya Şekil 2' de yer verilmiştir (Sullivan ve Glanz, 2005).

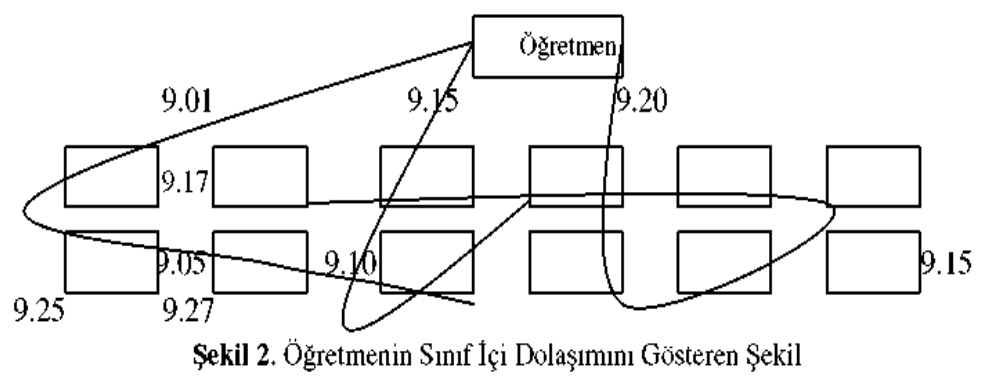

Genellikle gözlem süresi 35 dakikadır. Bu süre boyunca en çok hangi öğrencinin söz aldığına da bakılır. Gözlem sonunda dersin değerlendirmesi yapılmakta ve gözlem sonucu öğretmene aktarılmaktadır.

\section{Uyarlanmış Araçlar (Tailored Tools)}

Uyarlanmış araçlar kategorisinde "dönüt" ve "öğretmen-öğrenci etkileşimi" ile ilgili araçlara yer vermiştir. Uyarlanmış araçlar nicel tekniklerdir, çünkü bu tekniklerde sayısal veriler toplanmaktadır. Bu araçlar öğretmenin kendine özgü davranışlarını ve özellikle de öğretmenin yaratıcılığını geliştirmeyi amaçlamaktadır. Uyarlanmış araçların birçok türü bulunmaktadır. Ancak bu başlık altında iki örnek verilmiştir.

a. Dönüt (Feedback). Bu teknikte gözlem üzerinde anlaşılan belirli bir zamanda yapılmaktadır. Ancak gözleme yapılmadan önce mutlaka öğretmen ve gözlemci toplantı yapmalıdır. Bu toplantıda, öğretmen gözlemciye, öğrenciler hakkında bilgi vermektedir. Bu tekniğin kullanımında, gözlemci öğretmenin öğrencilere vermiş olduğu dönütlerin niteliğini belirlemeye çalışmaktadır. Gözlemci, öğretmenin öğrencilere verdiği dönütlerin, dakik, destek vermeyen, cesaretlendirici, irdeleyici olup olmadığını ya da olumlu pekiştireç içerip 
Çuhadaroğlu, E.O. \&Yılmaz, K. / Sosyal Bilimler Araştırmaları Dergisi. 1, (2007): 77-97

içermediğini belirlemeye çalışmaktadır. Gözlem öncesi toplantıda gözlemci ve öğretmen bu özellikler ile ilgili anahtar sözcükleri belirlemektedir (Şekil 3’teki gibi). Gözlemci bu tekniğin uygulanması sırasında, öğretmence verilen dönütleri kaydetmekte ve bu dönütlerin taraflı ya da tarafsız olduğunu da belirlemeye çalışmaktadır. Dönüt ile ilgili örnek bir çalışmaya Şekil 3'te yer verilmiştir (Sullivan ve Glanz, 2005).

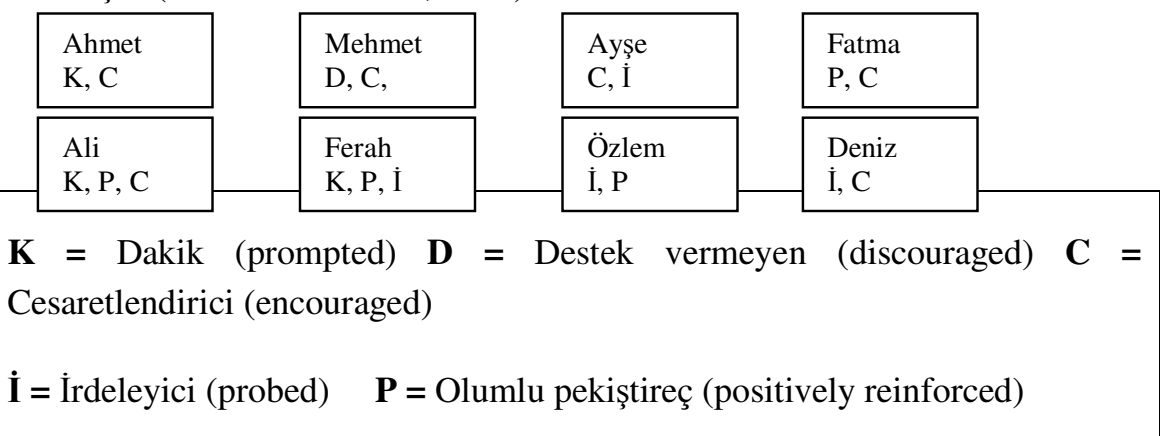

Şekil 3. Dönüt Şeması

Şekil 3'te de görüldüğü gibi gözlemci, gözlem yaptığı sınıfta bulunan öğrencilere verilen dönütlerin niteliğinin belirlemeye çalışmıştır. Örneğin öğretmen Ahmet adlı öğrenciye "dakik" bir şekilde ve "cesaretlendirici" dönütler vermiş̧ir. Şekil 3'ün işlerlik kazanabilmesi için, ders sırasında ne olduğunun tanımlanması, bu gözlemden ne sonuç çıkarıldığının belirlenmesi ve bu ders ile ilgili öğretmenle nasıl bir diyalog kurulacağının belirlenmesi gerekmektedir.

Dönüt tekniğinin kullanıldığı uygulamalarda, öğretmenlerin verdileri dönütlerde kullandıkları ifadelerin çeşitliliği, öğretmen dönütlerinin öğrencilerin verdikleri cevapların tekrarı ile sınırlı kalıp kalmadığı, dönütlerin sadece bilgi içerip içermediği, dönütlerin öğrencilerin duygu ve düşüncelerine yönelik olup olmadığı, akademik ve kişisel dönütler arasında paralellik kurulup kurulmadığı gibi konularda da analizler yapılabilir (Aydın, 2005).

b. Öğretmen-Öğrenci Etkileşimi (Teacher-Pupil Interaction). Bu tekniğin uygulanmasında öğretmen gözlemciden, sınıfın tamamı üzerinde değil, tek bir öğrenci üzerinde odaklanmasını istemektedir. Bu genellikle sınıftaki sorunlu/zor öğrencilerden biri olmaktadır ve öğretmen seçilen öğrencinin 
Çuhadaroğlu, E.O. \&Yılmaz, K. / Sosyal Bilimler Araştırmaları Dergisi. 1, (2007): 77-97

zorluklarını denetmene anlatmaktadır. Gözlemci öğrencinin davranışlarına, öğretmenin verdiği tepkiyi ölçmeye çalışmaktadır (Sullivan ve Glanz, 2005). Tablo 4'te öğretmen-öğrenci etkileşimi tekniği ile ilgili örnek bir çalışmaya yer verilmiştir.

Tablo 4. Öğretmen-Öğrenci Etkileşimi

\begin{tabular}{|c|c|c|}
\hline Zaman & Öğrenci: Ali Z. & Öğretmen: Mehmet K. \\
\hline \multirow[t]{2}{*}{ 09:05 } & $\begin{array}{l}\text { Diğer öğrencileri rahatsız } \\
\text { eder. }\end{array}$ & Öğrenci A’ya doğru yönelir. \\
\hline & $\begin{array}{ll}\text { Olumsuz } & \text { davranışını } \\
\text { durdurur. } & \end{array}$ & \\
\hline \multirow[t]{2}{*}{$09: 13$} & $\begin{array}{l}\text { Sırasından kalkarak sınıfta } \\
\text { dolaşmaya başlar }\end{array}$ & $\begin{array}{l}\text { Öğretmen öğrenci A ile göz } \\
\text { teması kurar. }\end{array}$ \\
\hline & Sandalyesine geri döndü. & \\
\hline \multirow[t]{2}{*}{ 09:18 } & Arkadaşlarıyla oynar. & Öğrenci A’yı eleştirir. \\
\hline & Cetvelini atar. & $\begin{array}{l}\text { Öğretmen öğrenci } \text { A'ya }^{\prime} \text { dersten sonra görüşeceğini } \\
\text { döyler. }\end{array}$ \\
\hline \multirow[t]{2}{*}{ 09:20 } & Dersi dinlemiyor. & $\begin{array}{l}\text { Öğretmen öğrenciye yaklaşır } \\
\text { ve sessizce yerine oturmasını } \\
\text { söyler. }\end{array}$ \\
\hline & Dersi dinlemeye başlar. & \\
\hline Tarih: & Sinıf: & Saat: \\
\hline
\end{tabular}

Kaynak: Glickman, C. D ve diğerleri. (2004). Supervision and Instructional Leadership: A Developmental Approach. USA: Allyn ve Bacon. Akt: Sullivan ve Glanz, 2005.

Tablo 4'te de görüldüğü gibi gözlemci Ali isimli öğrenciyi gözlemiş ve ders süresindeki davranışları ile ilgili notlar tutmuştur. Örneğin Ali diğer öğrencileri rahatsız ettiği zaman, öğretmen Ali'ye doğru yönelmiştir. Bunun üzerine Ali olumsuz davranışını durdurmuştur.

\section{Nitel Yaklaşımlar (Qualitative Approaches)}

Sınıf içi gözlem tekniklerine nitel yaklaşımlar başlığı altında, "tarafsız açık uçlu anlatım aracına", "katılanların açık uçlu gözlemine", "öğrenci merkezli öğrenme gözlemine" ve "sözlü olmayan tekniklere" yer verilmiştir. 
Çuhadaroğlu, E.O. \&Yılmaz, K. / Sosyal Bilimler Araştırmaları Dergisi. 1, (2007): 77-97

Achilles ve Gutmore'a göre (2006) açı uçlu teknikler ve kodlamalar öğretmen ve öğrenci gözlemlerinde sık sık kullanılmaktadır.

\section{Tarafsız Açık Uçlu Anlatım Aracı (Detached Open Ended Narrative Tool)}

$\mathrm{Bu}$ araçların kullanımı sırasında gözlemci her kişiyi, olayı, öğretmenin her girişimini gözlemekte, kritik olanları kayıt cihazı ile kaydetmektedir. Ancak bütün sözel iletişim kaydedilmemekte, gözlemci sadece dikkatini çeken her kişiyi, olayı ya da nesneyi yani kendince önemli gördüklerini kaydetmektedir. $\mathrm{Bu}$ önem, gözlemden önce öğretmen ile gözlemci arasındaki görüşmede saptanmaktadır. Tabi ki bu görüşmede gözlem sırasında kullanılacak kategoriler ve sorular belirlenmiş olmalıdır. Böylece sadece seçilmiş olan bölüm kaydedilmiş olmaktadır. Bu tekniğin kullanılmasında, gözlemler sayesinde sınıfta neler olduğu tarif edilmekte ve gözlem sonunda gözlemci genel bir sonuç çıkarmaktadır. Gözlemci ders bitiminde gözlemleri ile ilgili olarak öğretmene bilgi vermektedir (Sullivan ve Glanz, 2005).

\section{Katılanların Açık Uçlu Gözlemi (Participant Open Ended Observation)}

$\mathrm{Bu}$ teknik gözlemcinin sınıf içi etkinliklere katılması durumunda kullanılabilecek bir tekniktir. Bu teknikte gözlemci uygulamanın içinde yer almaktadır. Bundan dolayı, bu teknik gözden kaçabilecek olayların bile anlaşılmasına yardımcı olmaktadır. Sınıf içindeki ilişkiyi anlamının en iyi yolu bireysel durumları gözlemektir. Bu bağlamda gözlemci verilen kuralların uygulanması için gruplarla veya bireylerle çalışarak öğretmene yardımcı olabilmektedir. Gözlemci, çalışmalara katılmanın yanı sıra, sınıf içinde gözleyeceği durumlara göre çeşitli yaklaşımları da kullanabilmektedir. Örneği gözlemci notlar alabilmekte ya da daha sonra hatırlayabileceği şekilde bazı düşüncelerini çabucak not edebilmektedir. Gözlemcinin katılımından öğretmenin rahatsızlık duyması durumunda, öğretmen bu rahatsızlığını açıça belirtebilmelidir (Sullivan ve Glanz, 2005). 
Çuhadaroğlu, E.O. \&Yılmaz, K. / Sosyal Bilimler Araştırmaları Dergisi. 1, (2007): 77-97

\section{3. Öğrenci Merkezli Öğrenme Gözlemi (Child-Centered Learning Observation)}

$\mathrm{Bu}$ teknik yapısalcı öğrenme teorisine dayanmakta ve öğretmen ve gözlemciden daha çok öğrencilerin öğrenmelerine odaklanmaktadır. Bu teknikte öğrencilerin davranışlarına ve tutumlarına öğretmenin verdiği tepki ve öğrencilerle etkileşimi gözlemektedir. Bu tekniğin uygulanmasında gözlemci aşağıdaki soruları sorarak gözlem yapmaktadır (Sullivan ve Glanz, 2005):

- $\quad$ Öğrenciler öğrendi mi / düşünüyorlar mı?

- Öğrencilere ne tür sorular soruldu?

- Öğrencilerin tutumları nasıldı?

- Öğrencilere öğrenmeleri için ne tür farklı yöntemler uygulandı?

- Bilginin kaynağı kimdi?

- Öğrenciler birbirleriyle konuştular mı?

- Öğrenciler kendi öğrenmelerini biçimlendirebildi mi?

- $\quad$ Öğrenmeler değerlendirildi mi?

- Öğrenciler hakkında ne öğrendik?

Yukarıda da görüldüğü gibi, bu sorular tamamen öğrencilerin öğrenip öğrenmediklerini belirlemeye dönük sorularıdır. Çağdaş öğretim yöntemlerinin öğretmenden daha çok öğrenci merkezli olduğu düşünüldüğünde bu tekniğin yararlı bir teknik olduğu ileri sürülebilir. Bu teknik ile sınıflarda yapılan öğretim etkinliklerinin öğrenci merkezli mi yoksa öğretmen merkezli mi olduğu da belirlenebilir.

\section{Sözel Olmayan Teknikler (Nonverbal Techniques)}

Sözel olmayan tekniklerin kullanımında gözlemler kısa ziyaretler halinde ancak birden fazla yapılmaktadır. Bu tekniklerin uygulanması sırasında gözlemci öğretmenin kullanıldığı sözsüz iletişim araçlarını değerlendirmeye çalışmaktadır. Bu tekniğin kullanımında gözlemciden, sınıf içindeki öğretmenöğrenci ilişkisini yorumlaması beklenmektedir (Sullivan ve Glanz, 2005). Gözlemciden, takip ettiği ders sürecinde öğretmen-öğrenci ilişkisini, öğrencilerin yanında durma, öğrencilere dokunma, sınıfta dolaşma, gülümseme, 
Çuhadaroğlu, E.O. \&Yılmaz, K. / Sosyal Bilimler Araştırmaları Dergisi. 1, (2007): 77-97

baş sallama, sert bakma, işaret etme ve benzeri sözsüz davranış ölçütlerine göre değerlendirmesi beklenmektedir.

Tablo 5'te görüldüğü üzere sözel olmayan tekniklere ilişkin gözlem kartında çeşitli hareketler yer almaktadır. Bu hareketler sadece Tablo 5'teki hareketler ile sınırlı değildir. Gözlemci gözleyeceği hareketlere ekleme yapabilmekte ya da hareketlerin sayısını azaltabilmektedir. Örneğin Tablo 5'te de görüldüğü üzere, bölüm 1'de öğretmenin daha çok sınıf içindeki hareketleri ile ilgili konular yer alırken, bölüm 2'de daha çok jestler, mimikler ve benzeri hareketler ile ilgili, bölüm 3'de ses ile ilgili hareketler, bölüm 4'te ise cevap verilirken gösterilen samimiyet ile ilgili hareketler yer almaktadır.

Tablo 5. Sözel Olmayan Tekniklere İlişkin Gözlem Kartı Örneği

\begin{tabular}{|c|c|c|}
\hline Bölüm & Sözsüz Davranışlar & Gözlem \\
\hline Bölüm 1 & $\begin{array}{l}\text { Öğrencilerin yanında durma } \\
\text { Öğrencilere doğru hareket etme } \\
\text { Öğrencilere dokunma } \\
\text { Sınıfta dolaşma }\end{array}$ & \\
\hline Bölüm 2 & $\begin{array}{l}\text { Göz kontağı } \\
\text { Dokunma } \\
\text { Gülümseme } \\
\text { Baş sallama } \\
\text { Kollarını açma hareketi } \\
\text { Kaşlarını çatma } \\
\text { Sert bakma } \\
\text { Susmalarını işaret etme } \\
\text { İşaret etme } \\
\text { Kollarını çapraz yapma } \\
\text { Ellerini beline koyma }\end{array}$ & \\
\hline Bölüm 3 & $\begin{array}{l}\text { Ses tonu } \\
\text { Sesinin perdesini ayarlamak } \\
\text { Ritim çeşitliliği }\end{array}$ & \\
\hline Bölüim 4 & Cevaplara verilen içtenlik & \\
\hline
\end{tabular}


Çuhadaroğlu, E.O. \&Yılmaz, K. / Sosyal Bilimler Araştırmaları Dergisi. 1, (2007): 77-97

\section{Sonuç Yerine}

Eğitim ve eğitim yönetimi ile ilgili alanlarda olduğu gibi denetim konusunda da hızlı bir değişim yaşanmaktadır. Çağdaş denetim anlayışına göre öğretmenlerin ve denetmenlerin denetime bakış açısı da değişmektedir. Öyle ki denetim ile ilgili ilk etkinlikler kontrol amaçlı olarak yapılırken, daha sonraki çalışmaların geliştirme odaklı olduğu görülmektedir. Değişen konulardan birisi de artık denetimin sadece formlara bağlı kalınarak yapılan bir işlev olmaktan çıkmasıdır. Ayrıca günümüzde tek bir denetim anlayışının uygulanmasının sağlıklı sonuçlar verebileceği fikrinden uzaklaşılmaya da başlanmıştır. $\mathrm{Bu}$ değişimlerin denetimde kullanılan araç gereçlere de yansıdığı ve artık bu araç gereçlerin de değişmekte olduğu görülmektedir.

Denetimin temelinde gözlemin bulunulduğu düşünülürse, gözlem yapmak ve gözlem sonucunda bir sonuca varmak belli bir profesyonelliği gerektirmektedir. Ancak denetmenlerin farkında olması gereken sınıf için gözlem teknik ve araçları yukarıda sayılanlarla sınırlı değildir. Bu tamamen denetmenin kendini yetiştirmesiyle ve gelişmeleri takip etmesiyle orantılıdır. Yapılan gözlemin amaçlı olması ve belli ölçütlere dayanması ve denetmenle öğretmen arasındaki karşılıklı işbirliğine dayanması önemlidir. Bu bağlamda, yukarıda açıklanmaya çalışılan bütün bu tekniklerde de görüldüğü gibi çağdaş denetim tekniklerinin özünde öğretmen ile denetmenin işbirliği vardır.

Denetim etkinliklerinin öncelikli amacı eğitim-öğretim etkinliklerini geliştirmek olduğuna göre bu yaklaşım çağdaş denetim yaklaşımlarının özü olarak görülebilir. Ayrıca Türkiye gibi denetim sisteminde birçok problem yaşanan bir ülkede yapılan denetime etkinliklerinde müdürlerin ve denetmenlerin çok kısa gözlemlerle öğretmenleri değerlendirdikleri düşünüldüğünde sınıf içi gözlem tekniklerinin önemi ortaya çıkmaktadır. Çünkü bu tekniklerin kullanımı, gözlemler çok kısa sürelerde yapılmış olsa bile etkili sonuçlar elde edilmesini sağlamaktadır. Ayrıca bu tekniklerin farkında olan gözlemciler sınıflara neyi gözleyeceklerini ya da nelere dikkat edeceklerini bilerek girmektedirler. Sınıf içi gözlem teknikleri sınıf ortamındaki olayların görülmesine ve denetimin sürekli gelişme ilkesinin yerine getirilmesine de katk1 getirmektedir. 
Çuhadaroğlu, E.O. \&Yılmaz, K. / Sosyal Bilimler Araştırmaları Dergisi. 1, (2007): 77-97

Sınıf içi gözlem tekniklerinin uygulanabilmesi için denetmenlerin sınıf değerlendirme ve sınıf içi gözlem teknikleri konularında iyi yetişmiş olmaları gerekmektedir. Ayrıca bu tekniklerin uygulanabilmesi için eğitim sistemindeki denetmen sayısının da yeterli olması gerekmektedir. Buna göre mevcut denetmenlerin bu konular ile ilgili olarak bilgilendirilmeleri, yeni yetişecek olanların ise buna göre yetiştirilmeleri gerekmektedir.

\section{Kaynakça}

Acheson, K. A. ve Gall, M. D. (1997), Techniques In The Clinical Supervision Of Teachers: Preservice And Inservice Applications, New York: Longman.

Achilles, C. M. ve Gutmore, D. (2006), Classroom Research. In Fenwick W. English (Eds.), Encylopedia Of Educational Leadership And Administration.

California: Sage Publications Ltd.

Açıkgöz, K. (1996), Etkili Öğrenme Ve Öğretme, İzmir: Kanyılmaz Matbaası. Airasian, P. W. (1994), Classroom Assessment, New York: McGraw-Hill, Inc.

Angelo, T. A. ve Cross, K. P. (1993), Classroom Assessment Techniques: A Handbook For College Teachers, San Francisco, California: Jossey Bass Inc. Publishers.

Aydın, İ. (2005), Öğretimde Denetim, Ankara: Pegem A Yayıncılık.

Aydın, İ. (2004), “Öğretmen Performansının Değerlendirilmesinde Sınıf İçi Gözlem Teknikleri”, Eğitim ve Denetim, 1 (2): 14-18.

Başar, H. (2000), Eğitim Denetçisi, Ankara: Pegem A Yayıncılık.

Erçetin, Ş. (2000), Örgütsel Zekâ, Ankara: Nobel Yayıncılık.

Goldhammer, R., Anderson, R. H., ve Krajewski, R. J. (1980), Clinical Supervision: Special Methods For The Supervision Of Teachers, NY: Holt, Rinehart ve Winston.

Good, T. L. ve Mulryan, C. (1990), Teacher Ratings: A Call for Teacher Control and Self-Evaluation. In Johan Millman ve Linda Darling-Hammond (Eds.), The new handbook of teacher evaluation: assessing elementary and secondary school teachers. Thousand Oaks, CA: Corwin Press, Inc., A Sage Publications Company.

Gözütok, D. (2000), Öğretmenliğimi Geliştiriyorum, Ankara: Siyasal Kitabevi.

Hopkins, W. S. ve Moore, K. D. (1993), Clinical Supervision, USA: WCB Brown ve Bencmark Publishers.

http://iteso.mx/ ruth/03_retroalimentacion/02_observacion/guide.html, Guide to Classroom Observation, (20.02.2006). 
Çuhadaroğlu, E.O. \&Yılmaz, K. / Sosyal Bilimler Araştırmaları Dergisi. 1, (2007): 77-97

http://template.aea267.iowapages.org/lessonplan/. Madeline Hunter's Lesson Plan. (20.02.2006).

Murphy, K. R. ve Cleveland, J. N. (1995), Understanding Performance Appraisal, London: SAGE Publications.

Özgüven, İ. E. (2002), Çağdaş Eğitimde Psikolojik Danışma Ve Rehberlik, Ankara: PDREM Yayınları.

Pennekamp, M. ve Allen, T. (1998), A Guide To Classroom Observation And Instruction, http://www.humboldt.edu/ tha1/observ.html, (20.02.2006).

Peterson, K. D. (1995), Teacher Evaluation. Thousand Oaks, CA: Corwin Press, Inc.

Poster, C. ve Poster, D. (2005), Teacher Appraisal: Training And Implementation, London: Routledge Publishers.

Saban, A. (2002), Çoklu Zekâ Teorisi Ve Eğitim, Ankara: Nobel Yayın Dağıtım.

Sergiovanni, T. J. ve Starratt, R. J. (1993), Supervision A Redefinition, New York: McGraw-Hill, Inc.

Stodolsky, S. S. (1990), Classroom Observation. In Johan Millman ve Linda DarlingHammond (Eds). The New Handbook Of Teacher Evaluation: Assessing Elementary And Secondary School Teachers. Thousand Oaks, CA: Corwin Press, Inc.

Sullivan, S. ve Glanz, J. (2005), Supervision That Improves Teaching Strategies And Techniques, USA: Sage Publication.

Üstünlüoğlu, E. (2000), Öğretmenlerin Doğrudan Gözlem Yoluyla İşbirlikli Öğretimi Gerçekleştirmesi, Milli Eğitim Dergisi, 145. http://yayim.meb.gov.tr/dergiler/145/ustunoglu.htm, (20.02.2006).

Wragg, E. C. (1987), Teacher Appraisal: A Practical Guide. Basingstoke: Macmillan Education.

www.windows.ucar.edu/teacher_resources/sci_schools/HunterLessonP.pdf. The

Madeline Hunter Model, (20.02.2006). 